CZASOPISMO INŻYNIERII LĄDOWEJ, ŚRODOWISKA I ARCHITEKTURY JOURNAL OF CIVIL ENGINEERING, ENVIRONMENT AND ARCHITECTURE JCEEA, t. XXXIII, z. 63 (3/16), lipiec-wrzesień 2016, s. 447-460

Milena STETTNER ${ }^{1}$

\title{
REWITALIZACJA ZASOBÓW MIESZKANIOWYCH W MIASTACH DO 10 TYS. MIESZKAŃCÓW SZANSĄ NA ROZWÓJ MAŁYCH MIAST
}

\begin{abstract}
Współczesne małe miasta mają wiele problemów urbanistyczno-społecznych. Zachwiana równowaga demograficzna, brak potencjału ekonomicznego, degradacja odgórnych obszarów w mieście, wyludnianie i pustoszenie śródmieść to główne aspekty, na które autorka zwraca uwagę w swoim artykule. Jak powstrzymać niszczący proces przestrzenny i społeczny oraz doprowadzić do zrównoważonego rozwoju? Rewitalizacja jako działanie kompleksowe może być dobrym rozwiązaniem. $\mathrm{W}$ artykule przedstawiono badania wszystkich małych miast do 10 tys. mieszkańców (54) w województwie dolnośląskim pod względem zmian demograficznych i ekonomicznych (liczba ludność w podziale na grupy ekonomiczne, saldo migracji i przyrost naturalny) oraz w wyniku delimitacji wybrano 9 (Głuszyca, Lądek-Zdrój, Lubawka, Lwówek Śląski, Pieszyce, Polanica-Zdrój, Stronie Śląskie, Szklarska Poręba, Ziębice) w najgorszej kondycji społeczno-ekonomicznej i przebadano je pod kątem stanu zasobów mieszkaniowych (dostęp do sieci wodociągowej, kanalizacyjnej i gazowej, liczba pustostanów i powierzchnia na 1 mieszkańca). Celem badania było ukazanie problemu degradacji centralnych obszarów w małych miastach do 10 tys. mieszkańców i próba zdefiniowania wniosków dla władz jednostek samorządu terytorialnego, mających na celu zastosowanie np. Europejskiego Programu Rozwoju Obszarów Wiejskich, jako dobrej praktyki. Niewątpliwie dużym problemem w procesach naprawczych centralnych obszarów w mieście jest zróżnicowanie zabudowy pod względem struktury własności, jednak przez wzgląd na większość w zasobie gminnym, można zastosować naprawcze programy unijne.
\end{abstract}

Słowa kluczowe: modernizacja, Europejski Program Rozwoju Obszarów Wiejskich, śródmieście, równowaga demograficzna, instalacje techniczno-sanitarne

\section{Wprowadzenie}

"Ujemny przyrost naturalny, migracje i dość duża działalność deweloperów, powoduje narastający kłopot rozlewania się miasta i niszczenia jego ,serca” [1]. Wnioski kończące badania znaczenia odnowy małych miast dla społeczności lokalnej skłoniły mnie do dalszych badań dotyczących zasobów mieszkaniowych

\footnotetext{
${ }^{1}$ Milena Stettner, Politechnika Wrocławska, Katedra Urbanistyki i Procesów Osadniczych, ul. Prusa 53-55, 50-377 Wrocław, 513166801, milena.stettner@pwr.edu.pl, milena.stettner@gmail.com
} 
i jakości życia w niemal najmniejszych jednostkach miejskich, czyli miastach do 10 tys. mieszkańców. Zmiany urbanistyczne, demograficzne i ustrojowe, doprowadzają do ciągłego wyludniania śródmieść i marginalizacji najbiedniejszej grupy mieszkańców. Już w Nowej Karcie Ateńskiej zwrócono uwagę na istotny problem segregacji społeczeństwa w miastach: „Obszary zamieszkałe przez bogatych mieszkańców wykazują tendencję do tworzenia zamkniętych enklaw, podczas gdy ubodzy mieszkańcy pozostają bezdomni lub żyją w upadających śródmieściach miast lub na przedmieściach."2 [2]. Bardzo ważne w tym aspekcie jest doprowadzenie do wyrównania standardów zabudowy mieszkaniowej wielorodzinnej w śródmieściach małych miast z jakością nowoczesnych lokali mieszkalnych, co może skutkować zahamowaniem niszczenia wartościowych kulturowo i społecznie centralnych obszarów miasta. Rewitalizacja, jako działanie interdyscyplinarne, łączące w sobie procesy technologiczne (poprawa instalacji technicznosanitarnych), społeczne (poprawa jakości życia) i przestrzenne (poprawa urbanistyki miasta), może być szansą w rozwoju małego miasta. Słowa A. Rybka, B. Walicka-Góral: „,...) stare zespoły mieszkaniowe stanowią często wartościowy dorobek kultury, pozwalają rozpoznać nasze miasta, pozostają nierzadko jedynym ich identyfikatorem."3, podkreślają istotę centralnych obszarów miasteczka [3].

\section{Podstawy teoretyczne}

\subsection{Istota rewitalizacji i modernizacji zasobów mieszkaniowych}

Rewitalizacja, wśród wielu procesów odnowy, odbudowy obszarów zdegradowanych, jest jednym z najbardziej kompleksowych i najlepiej oddających istotę przemiany struktury funkcjonalno-przestrzennej miasta. S. Kaczmarek rozgranicza w kategoriach terminologicznych: restrukturyzację, rewaloryzację, renowację, rehabilitację i rewitalizację, jednak jako proces przemiany obszarów kryzysowych, w celach naprawczych, nadania nowej funkcji i wartości, podkreśla właśnie rolę rewitalizacji [4]. Właściwą definicją stosowaną w środowisku naukowym urbanistów traktuje się słowa K. Skalskiego: ,„...) jako kompleksowy program remontów, modernizacji i rewaloryzacji zabudowy i przestrzeni publicznych na wybranym obszarze, najczęściej dzielnicy miasta, w powiązaniu z rozwojem gospodarczym i społecznym. Rewitalizacja to powiązanie działań technicznych, jak remonty z programami na rzecz ożywienia gospodarczego i działaniem na rzecz rozwiązania problemów społecznych, występujących na tych obszarach: bezrobocie,

\footnotetext{
${ }^{2}$ Europejska Rada Urbanistów: Nowa Karta Ateńska 2003 Wizja miast XXI wieku, Wydawnictwo Alinea, Firenze 2003, s. 16

${ }^{3}$ Rybka A., Walicka-Góral B.: Rewitalizacja komunalnych zasobów mieszkaniowych, Czasopismo techniczne Architektura, Zeszyt 14, Wydawnictwo Politechniki Krakowskiej, Kraków 2010, s. 162
} 
przestępczość, brak równowagi demograficznej”4 [5]. Bardzo ważnym aspektem rewitalizacji jest próba doprowadzenia do zrównoważonego rozwoju i harmonii danego terenu poprzez ,przywrócenie do życia”. Zgodnie z etymologią słowo „rewitalizacja”, pochodzące z języka łacińskiego jest połączeniem dwóch znaczeń „vitalis - należący do życia, zdolny do życia, dający życie, wart życia” i „re znów, na nowo, powtórnie." "6].

W niniejszym artykule autorka zwraca uwagę na zasoby mieszkaniowe zabudowy wielorodzinnej, dlatego $\mathrm{w}$ tym miejscu warto przytoczyć słowa J. M. Chmielewskiego, odnoszące się do naprawy środowiska mieszkaniowego: „modernizacja zasobów mieszkaniowych jest działaniem przyczyniającym się do poprawy warunków mieszkaniowych, sprzyja również rozwiązywaniu problemów społecznych, przede wszystkim przez dostosowywanie wartości użytkowych istniejącej zabudowy do obecnych potrzeb użytkowników. Działa także na rzecz tworzenia lepszego klimatu społecznego w środowisku zamieszkania. Przy zapewnieniu ze strony państwa i władz komunalnych odpowiedniego systemu finansowego, pozwala także na utrzymanie dostępności mieszkań w zmodernizowanych budynkach dla rodzin o niskich dochodach"6 [7]. Podobne potrzeby śródmieść miast, do prezentowanych przez autorkę, przywołuje w swym rozdziale Alina Muzioł-Węcławowicz, na podstawie badań w projekcie badawczym „Rewitalizacja miast polskich jako sposób zachowania dziedzictwa materialnego i duchowego oraz czynnik zrównoważonego rozwoju" [8]. Mając świadomość, że „,miasta nie składają się tylko z domów i ulic, ale z ludzi i ich nadziei" " [9] patrzymy na jednostkę miejską przez pryzmat osób w niej mieszkających. W wyniku tego możemy zdefiniować najważniejsze potrzeby małego miasta do jego zrównoważonego funkcjonowania, $\mathrm{tj}$. poprawa stanu technicznego zabudowy, zapewnienie instalacji techniczno-sanitarnych, nadanie znaczenia gospodarczego tym obszarom, a także zjednanie osób w nim mieszkających, pogłębiając ich tożsamość i identyfikację z otoczeniem [8]. Co potwierdzają słowa K. Krzysztofka „Korzyści są niebagatelne: dbałość o dziedzictwo, co prawda jako zasób ekonomiczny, ale jednak walor, reintegracja z teraźniejszością, co się na ogół nie udaje tradycyjnym publicznym przedsięwzięciom" ${ }^{\text {" }}[10]$.

\footnotetext{
${ }^{4}$ Skalski K.: Rewitalizacja obszarów zabytkowej zabudowy, Praca zbiorowa pod red. Jurek K., Majchrzak M. Lokalne strategie mieszkaniowe oraz programy gospodarowania zasobem mieszkaniowym gmin, Urząd Mieszkalnictwa i Rozwoju Miast, Kraków 2001

${ }^{5}$ Hajduga P.: Rewitalizacja przestrzeni śródmiejskiej na przykładzie Świdnicy - wybrane aspekty, Gospodarka i przestrzeń, Prace naukowe Uniwersytetu Ekonomicznego we Wrocławiu, nr 341, Wrocław 2014, s. 39

${ }^{6}$ Chmielewski J. M.: Teoria urbanistyki w projektowaniu i planowaniu miast, Oficyna Wydawnicza Politechniki Warszawskiej, Warszawa 2005, s. 152

${ }^{7}$ Św. Augustyn

${ }^{8}$ Krzysztofek K.: Tendencje zmian w przestrzeni późnonowoczesnego miasta, Praca zbiorowa pod red. Jałowiecki B. i in. Przemiany miasta: wokół socjologii Aleksandra Wallisa, Wydawnictwo Naukowe „Scholar”, Warszawa 2005, s. 43
} 


\subsection{Stan zasobów mieszkaniowych w polskich miastach}

Obecny stan badań dotyczący terenów zdegradowanych w polskich miastach pokazuje, że śródmieścia stanowią największy odsetek wszystkich obszarów wymagających rewitalizacji ${ }^{9}$ [11]. Śródmieście to najstarsza część każdego miasta, w której w większości, zabudowa powstała przed II Wojną Światową, jako zasób mieszkaniowy gminy. Ze względu na datę powstania budynki obecnie wymagają wielu remontów i modernizacji. Epoka socjalizmu, w której powszechnie zaniedbywano wartość kulturową i ekonomiczną centrów miast [8], a także dążono do rozbudowy powierzchni zurbanizowanej miasta (rys.1), obecnie doprowadziła do degradacji śródmieść i pauperyzacji ludności mieszkającej w tej części miasta. Segregacja ludności ze względu na pozycję społeczną i zasób materialny, zmiany ustrojowe, niewyjaśniona sytuacja podmiotów własności danych nieruchomości, to wszystko problemy dzisiejszych samorządów terytorialnych dotyczące centralnych obszarów w miasteczkach [12].

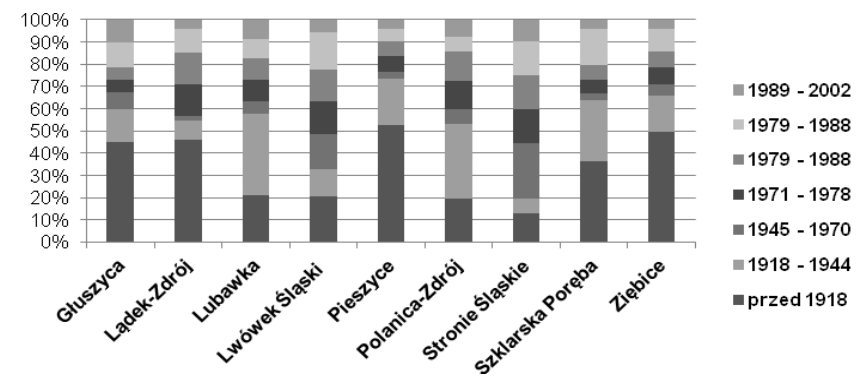

Rys. 1. Zasoby mieszkaniowe, wg daty powstania, w wybranych małych miastach. Źródło: dane GUS, opracowanie własne

Fig. 1. Housing, by date of creation, in some small towns. Source: GUS, own elaboration

\section{Badania}

\subsection{Cel badań}

Celem badań jest próba wskazania problemu jakim jest degradacja i wyludnianie centralnych obszarów w mieście, a także określenie przyczyn zubożenia małych miast i braku możliwości konkurowania $\mathrm{z}$ większymi jednostkami miejskimi. Brak stabilności demograficznej i ekonomicznej, a także brak dominującej funkcji w mieście, doprowadza do zamierania nie tylko śródmieść, ale również całych małych miast. Europejski Program Rozwoju Obszarów Wiejskich, do którego można włączyć również małe miasta, mający na celu wsparcie jednostek samorządu terytorialnego oraz poprawy jakości życia mieszkańców, w tym za-

\footnotetext{
${ }^{9}$ Badania realizowane w ramach projektu badawczego na zlecenie Ministerstwa Rozwoju Regionalnego w latach 2007-2009 [3]
} 
pewnienia podstawowych usług oraz infrastruktury technicznej, może być możliwością realizacji rewitalizacji w miastach, które wzięły udział w badaniu (przedstawione w niniejszym artykule), jako zastosowanie dobrej praktyki, co jest głównym celem rozpoczętych badań [13].

\subsection{Metody badań}

Do badania wzięto wszystkie (54) małe miasta do 10 tys. mieszkańców w województwie dolnośląskim (rys.2, tab.1). Badania początkowe dotyczyły analizy stanu równowagi demograficznej, potencjału ekonomicznego i gospodarczego danej jednostki miejskiej na podstawie danych statystycznych GUS. Kolejnym etapem było wybranie miast o malejącej liczbie ludności, zwłaszcza z grupy ekonomicznej produkcyjnej i przedprodukcyjnej, o ujemnym współczynniku migracji i ujemnym przyroście naturalnym, jako jednostek, którym konieczne jest udzielenie wsparcia i znalezienia przyczyn degradacji, w celu umożliwienia im przyszłego rozwoju. Kolejnym etapem było badanie w wybranych miastach: zasobów mieszkaniowych w postaci dostępności do poszczególnych instalacji technicznosanitarnych w zabudowie mieszkaniowej wielorodzinnej, ilości pustostanów i powierzchni użytkowej w mieszkaniach na 1 osobę.

\subsection{Lokalizacja badań}

W badaniu wzięły udział wszystkie (54) małe miasta do 10 tys. mieszkańców w województwie dolnośląskim w rozkładzie na 22 powiaty. W wyniku wstępnej delimitacji obszaru badań, który jest przedmiotem niniejszego artykułu, wyłoniono 9 miast prezentujących spadek liczby ludności w latach 1995-2013, w tym potencjału ekonomicznego, tj. spadek ludności w wieku produkcyjnym i przedprodukcyjnym. Wybrane 9 małych miast zaznaczono na rysunku nr 3.

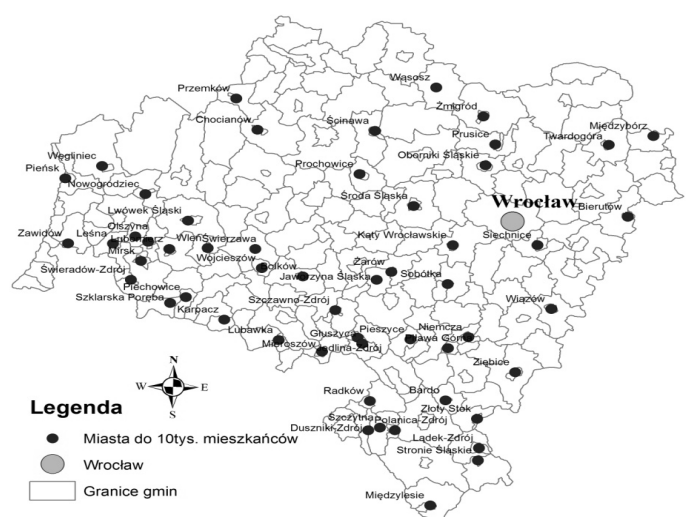

Rys. 2. Małe miasta do 10 tys. mieszkańców w województwie dolnośląskim

Fig. 2. Small towns up to 10 thousand residents in Lower Silesia 
Tabela 1. Małe miasta do 10 tys. mieszkańców w województwie dolnośląskim

Table 1. Small towns up to 10 thousand residents in Lower Silesia

\begin{tabular}{|c|c|c|c|}
\hline \multirow[t]{2}{*}{$\begin{array}{l}\text { Powiat lwówecki: } \\
\text { - Mirsk, } \\
\text { - Gryfów Śláski, } \\
\text { - Lwówek Śląski, } \\
\text { - Lubomierz, } \\
\text { - Wleń. }\end{array}$} & \multirow{2}{*}{$\begin{array}{l}\text { Powiat kłodzki: } \\
\text { - Lądek Zdrój, } \\
\text { - Międzylesie, } \\
\text { - Radków, } \\
\text { - Duszniki Zdrój, } \\
\text { - Polanica Zdrój, } \\
\text { - Stronie Śląskie, } \\
\text { - Szczytna. } \\
\end{array}$} & $\begin{array}{l}\text { Powiat wałbrzyski: } \\
\text { - Szczawno-Zdrój, } \\
\text { - Mieroszów, } \\
\text { - Głuszyca, } \\
\text { - Jedlina-Zdrój. }\end{array}$ & $\begin{array}{l}\text { Powiat dzierżoniow- } \\
\text { ski: } \\
\text { - Pieszyce, } \\
\text { - Niemcza, } \\
\text { - Piława Górna. } \\
\end{array}$ \\
\hline & & $\begin{array}{l}\text { Powiat legnicki: } \\
\text { - Prochowice. }\end{array}$ & $\begin{array}{l}\text { Powiat średzki: } \\
\text { - Środa Śląska. }\end{array}$ \\
\hline $\begin{array}{l}\text { Powiat bolesławiecki: } \\
\text { - Nowogrodziec. }\end{array}$ & $\begin{array}{l}\text { Powiat górowski: } \\
\text { - Wąsosz. }\end{array}$ & $\begin{array}{l}\text { Powiat lubiński: } \\
\text { - Ścinawa. }\end{array}$ & $\begin{array}{l}\text { Powiat strzeliński: } \\
\text { - Wiązów. }\end{array}$ \\
\hline $\begin{array}{l}\text { Powiat kamiennogór- } \\
\text { ski: } \\
\text { - Lubawka. }\end{array}$ & $\begin{array}{l}\text { Powiat złotoryjski: } \\
\text { - Świerzawa, } \\
\text { - Wojcieszów. } \\
\end{array}$ & $\begin{array}{l}\text { Powiat polkowicki: } \\
\text { - Chocianów, } \\
\text { - Przemków. } \\
\end{array}$ & $\begin{array}{l}\text { Powiat świdnicki: } \\
\text { - Żarów, } \\
\text {-Jaworzyna Śląska. } \\
\end{array}$ \\
\hline $\begin{array}{l}\text { Powiat trzebnicki: } \\
\text { - Żmigród, } \\
\text { - Prusice, } \\
\text { - Oborniki Śląskie. }\end{array}$ & $\begin{array}{l}\text { Powiat oleśnicki: } \\
\text { - Bierutów, } \\
\text { - Twardogóra, } \\
\text { - Międzybórz. }\end{array}$ & $\begin{array}{l}\text { Powiat jeleniogórski: } \\
\text {-Szklarska Poręba, } \\
\text { - Piechowice, } \\
\text { - Karpacz. }\end{array}$ & $\begin{array}{l}\text { Powiat lubański: } \\
\text { - Leśna, } \\
\text {-Świeradów-Zdrój, } \\
\text { - Olszyna. }\end{array}$ \\
\hline $\begin{array}{l}\text { Powiat wrocławski: } \\
\text {-Kąty Wrocławskie, } \\
\text { - Sobótka, } \\
\text { - Siechnice. }\end{array}$ & $\begin{array}{l}\text { Powiat zgorzelecki: } \\
\text { - Zawidów, } \\
\text { - Pieńsk, } \\
\text { - Węgliniec. }\end{array}$ & $\begin{array}{l}\text { Powiat ząbkowicki: } \\
\text { - Ziębice, } \\
\text { - Złoty Stok, } \\
\text { - Bardo. }\end{array}$ & $\begin{array}{l}\text { Powiat jaworski: } \\
\text { - Bolków. }\end{array}$ \\
\hline
\end{tabular}

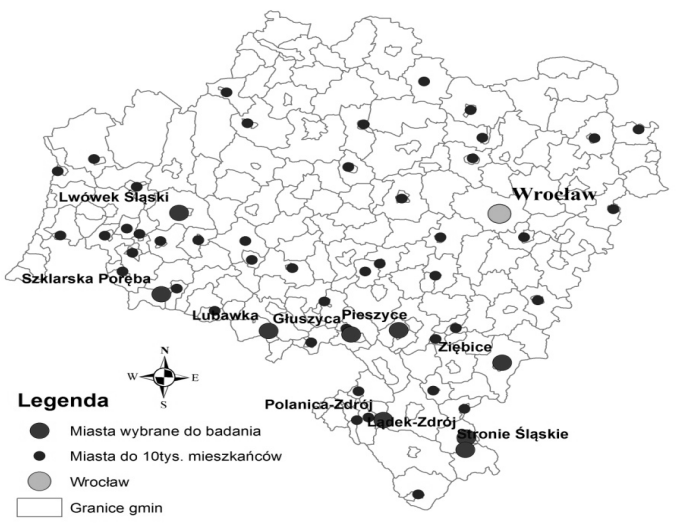

Rys. 3. Wybrane do badania małe miasta do 10 tys. mieszkańców w województwie dolnośląskim

Fig. 3. Selected for testing small towns to 10 thousand residents in Lower Silesia

Wybrane 9 miast, prezentujących najgorszy stan demograficzny i ekonomiczny, w większości można zauważyć przy zachodniej granicy województwa dolnośląskiego, a tym samym granicy państwa. Kolejną zależnością, która jednoczy wskazane w wyniku delimitacji miasta jest ich położenie wśród innych miast 
do 10 tys. mieszkańców. Nagromadzenie jednostek o tak niskiej liczbie ludności jest niestety dużym problemem urbanistycznym.

\subsection{Wyniki badań}

\subsubsection{Badanie równowagi demograficznej i potencjału ekonomicznego}

We wszystkich małych miastach do 10 tys. mieszkańców przeanalizowano zmiany demograficzne w latach 1995-2013 wraz z uwzględnieniem rozkładu na poszczególne grupy ekonomiczne (rys.4-7). Ze względu na czytelność wykresów prezentowanych $\mathrm{w}$ artykule na rycinach przedstawiono tylko wybrane miasta, które spełniają określone kryteria do dalszych badań, tj. spadek liczby ludności, ujemny przyrost naturalny, ujemne saldo migracji oraz brak potencjału ekonomicznego na skutek malejącej liczby ludności w wieku przedprodukcyjnym i produkcyjnym oraz rosnącej w wieku poprodukcyjnym. Starzejące się społeczeństwo, brak zaplecza ekonomicznego w postaci ludności do 18 roku życia oraz ujemne saldo migracji, sprawia, że miasta potrzebują wsparcia z zewnątrz do zachowania równowagi i doprowadzenia do utrzymania ciągłego rozwoju, również rozwoju zrównoważonego. W wyniku wstępnej delimitacji wskazano 9 miast: Głuszycę, Lądek-Zdrój, Lubawkę, Lwówek Śląski, Pieszyce, Polanicę-Zdrój, Stronie Śląskie, Szklarską Porębę i Ziębice. Wśród wybranych małych miast, w najgorszej sytuacji jest Stronie Śląskie, Szklarska Poręba i Lądek-Zdrój, prezentujące największy procentowy spadek liczby ludności, w przyjętym okresie czasu. Szklarska Poręba i Lądek-Zdrój to miasta turystyczne. Czy tak dominująca funkcja wystarczy do zrównoważonego funkcjonowania miasta? Ludność napływowa na ferie, wakacje, to tymczasowy zastrzyk gospodarczy dla tak małych jednostek miejskich, istotna w tym momencie będzie analiza zasobów mieszkaniowych oraz jakość życia jaką oferują mieszkańcom i turystom, co zaprezentuję w dalszej części artykułu.

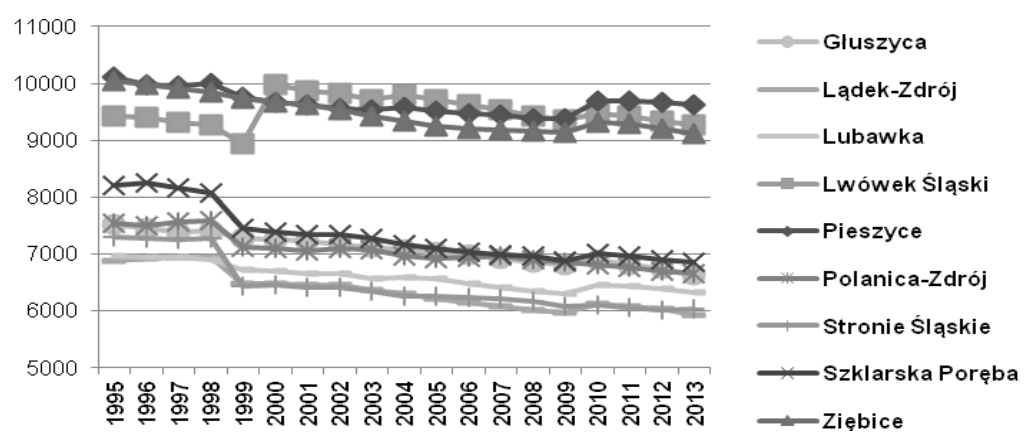

Rys. 4. Liczba ludności w wybranych małych miastach w latach 1995-2013. Źródło: dane GUS, opracowanie własne

Fig. 4. The population in selected small towns in the years 1995-2013. Source: GUS, own elaboration 


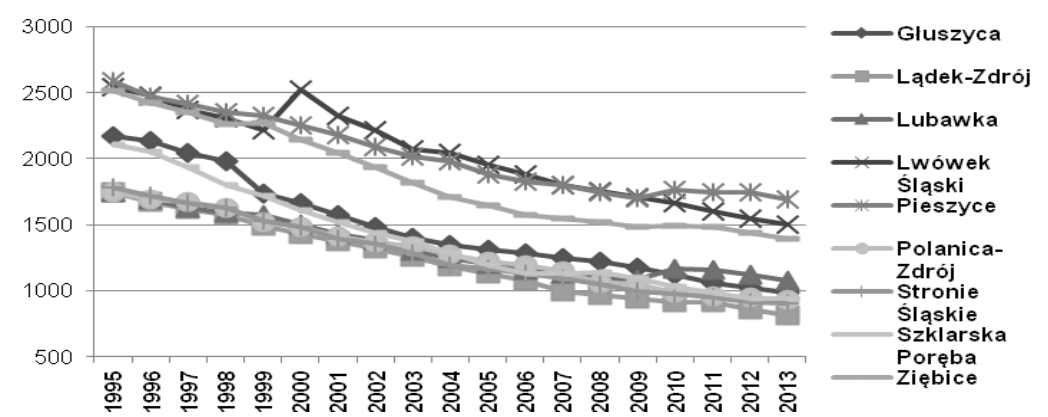

Rys. 5. Liczba ludności w wieku przedprodukcyjnym w wybranych małych miastach w latach 1995-2013. Źródło: dane GUS, opracowanie własne

Fig. 5. The number of pre-working age population in selected small towns in the years 1995-2013. Source: GUS, own elaboration

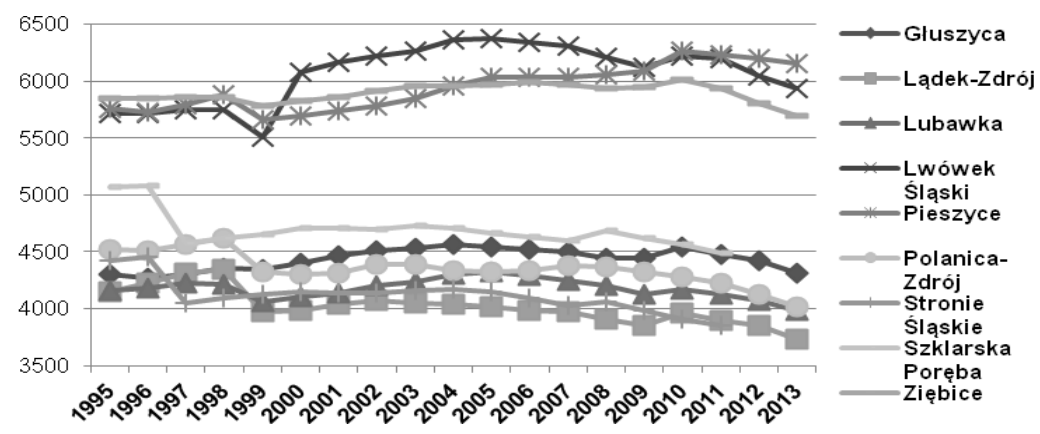

Rys. 6. Liczba ludności w wieku produkcyjnym w wybranych małych miastach w latach 1995-2013. Źródło: dane GUS, opracowanie własne

Fig. 6. The number of working-age population in selected small towns in the years 1995-2013. Source: GUS, own elaboration

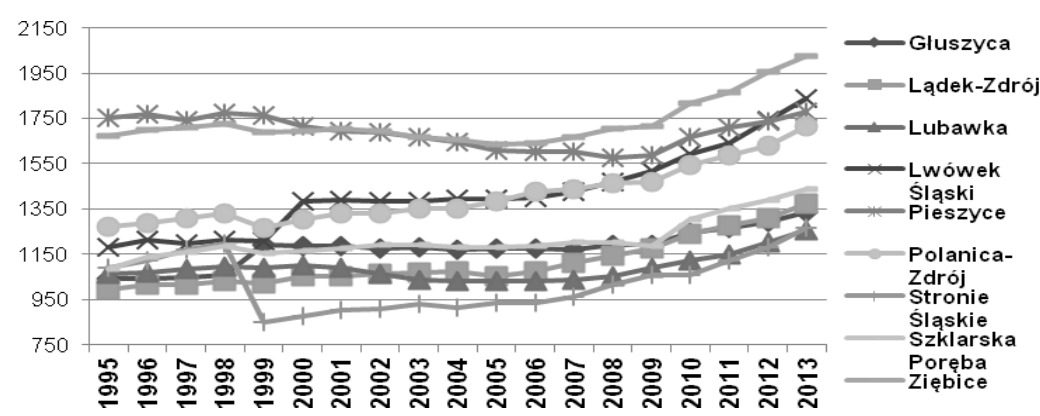

Rys. 7. Liczba ludności w wieku poprodukcyjnym w wybranych małych miastach w latach 1995-2013. Źródło: dane GUS, opracowanie własne

Fig. 7. The population of working age in selected small towns in the years 1995-2013. Source: GUS, own elaboration 
Saldo migracji oraz przyrost naturalny zaprezentowane na rysunkach 8 i 9 , potwierdzają niestety brak równowagi demograficznej we wszystkich badanych małych miastach. Zaledwie 2 miasta: Pieszyce i Lądek-Zdrój w ostatnich latach mają dodatnie saldo migracji, w pozostałych można zauważyć narastający spadek ludności, zarówno napływowej, jak i nowonarodzonej. Najgorszy stan ukazują miasta: Głuszyce, Lwówek Śląski i Ziębice.

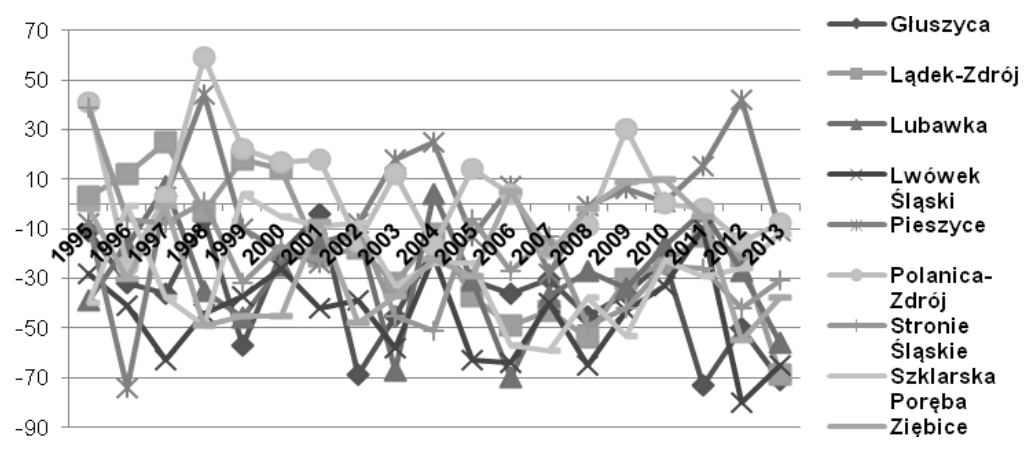

Rys. 8. Saldo migracji w wybranych małych miastach w latach 1995-2013. Źródło: dane GUS, opracowanie własne

Fig. 8. The balance of migration in selected small towns in the years 1995-2013. Source: GUS, own elaboration

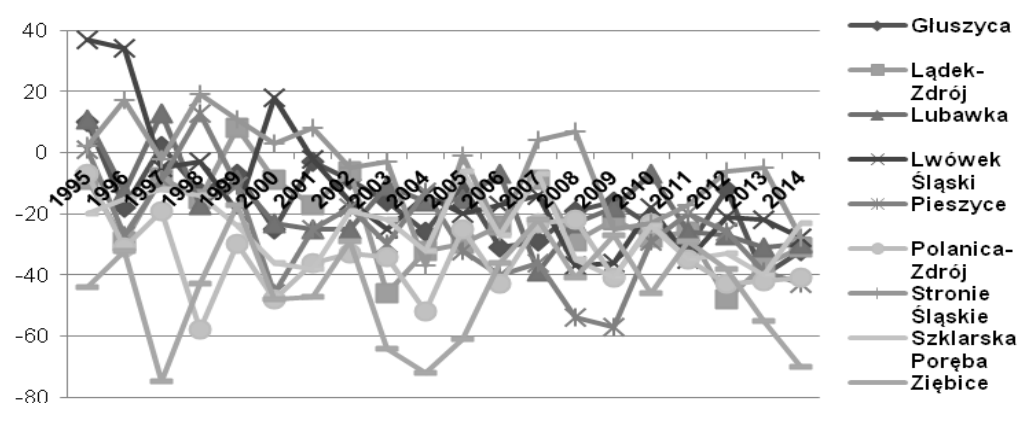

Rys. 9. Przyrost naturalny w wybranych małych miastach w latach 1995-2013. Źródło: dane GUS, opracowanie własne

Fig. 9. The natural increase in selected small towns in the years 1995-2013. Source: GUS, own elaboration

\subsubsection{Badanie stanu zasobów mieszkaniowych}

Drugim etapem było badanie zasobów mieszkaniowych m.in. ilości budynków niezamieszkanych (rys.10), dostępności do sieci wodociągowej, kanalizacyjnej i gazowej (rys.11-13) oraz powierzchni użytkowej na 1 mieszkańca (rys.14) w 9 wybranych małych miastach województwa dolnośląskiego. Wśród wszystkich 
zaprezentowanych miast największy wzrost liczby pustostanów w ciągu ostatnich 10 lat można zauważyć w Polanicy-Zdrój z 0 do 26 budynków. W pozostałych jednostkach miejskich liczba pustostanów waha się w granicach 5-15 budynków. Niewątpliwie nierozłączną przyczyną tak dużej ilości budynków niezamieszkanych jest jakość zasobów mieszkaniowych zabudowy wielorodzinnej m.in. dostępność do infrastruktury technicznej. Wśród miast o najgorszej kondycji można znaleźć właśnie Polanicę-Zdrój, która prezentuje dostępność do sieci gazowej dla ok. 70\% wszystkich mieszkańców, podobnie jak Szklarska Poręba, Stronie Śląskie i Pieszyce. Pieszyce to miasto o skrajnych wartościach co do dostępności nie tylko sieci gazowej, ale również wodociągowej ok. 65\% i kanalizacyjnej ok. 25\%. Pozostałe jednostki miejskie, z wyjątkiem Szklarskiej Poręby przy sieci kanalizacyjnej ok. 50-60\% i Stronia Śląskiego przy sieci wodociągowej ok. 85\%, mają podobne wyniki ok. 95\% dla sieci wodociągowej i 80-90\% dla sieci kanalizacyjnej.

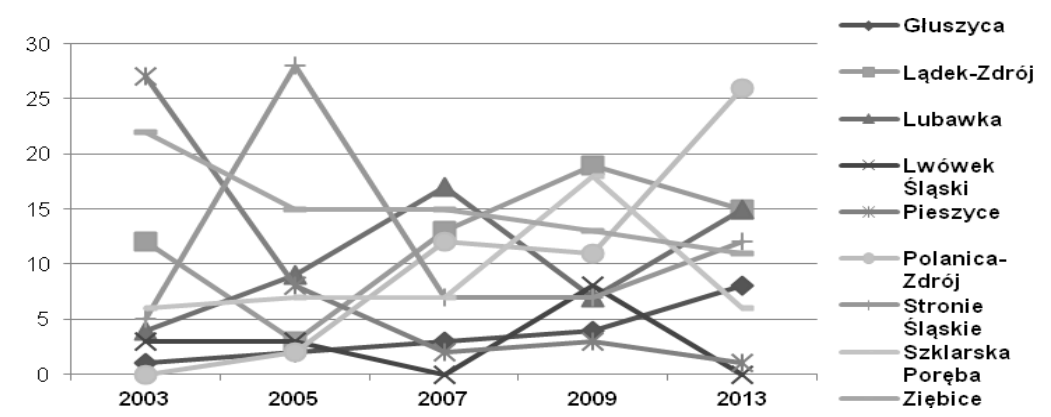

Rys. 10. Budynki niezamieszkane w zasobie gminy w wybranych małych miastach w latach 2003-2013 Źródło: dane GUS, opracowanie własne

Fig. 10. Resource uninhabited buildings in municipalities in selected small towns in the years 2003-2013 Source: GUS, own elaboration

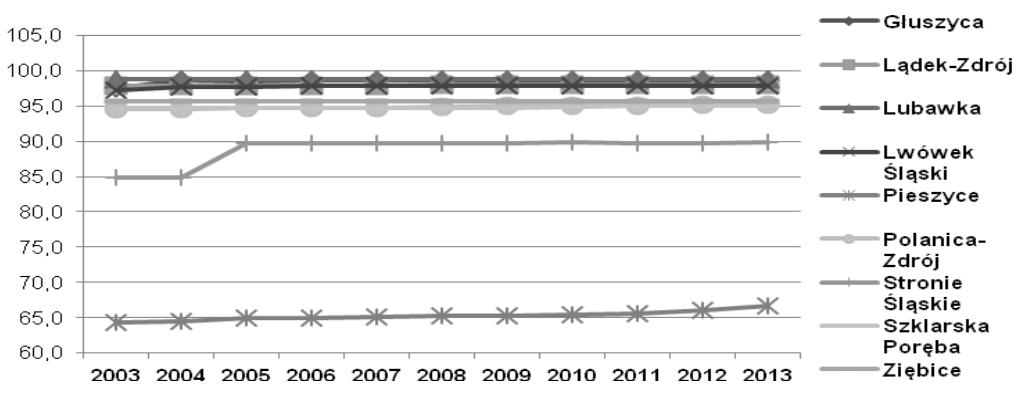

Rys. 11. Liczba osób korzystających z sieci wodociągowej w wybranych małych miastach w latach 2003-2013. Źródło: dane GUS, opracowanie własne

Fig. 11. The number of people using the water supply network in selected small towns in the years 2003-2013. Source: GUS, own elaboration 


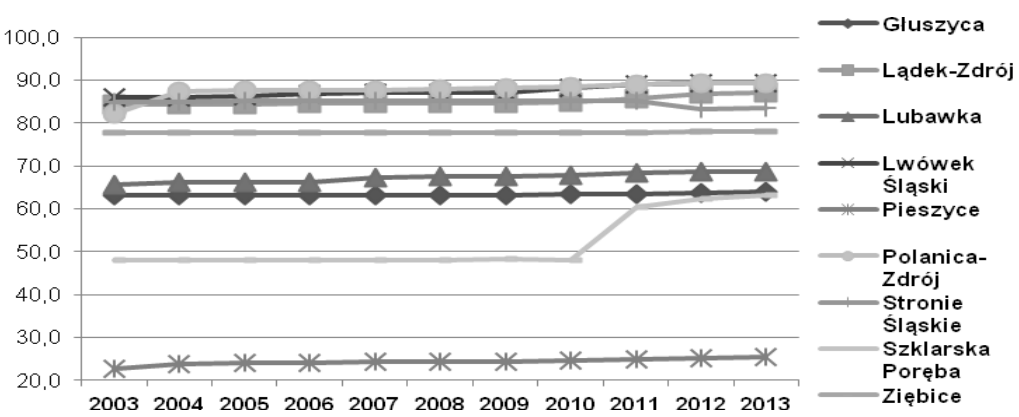

Rys. 12. Liczba osób korzystających z sieci kanalizacyjnej w wybranych małych miastach w latach 2003-2013. Źródło: dane GUS, opracowanie własne

Fig. 12. The number of people using the sewage network in selected small towns in the years 2003-2013 Source: GUS, own elaboration

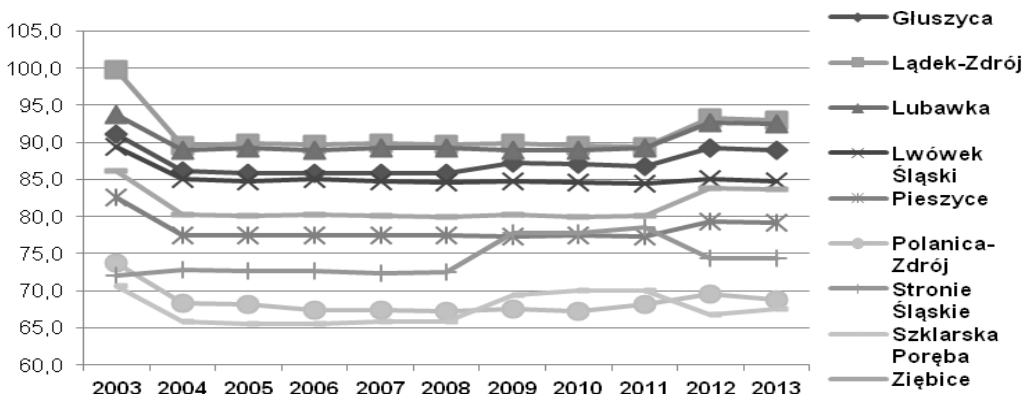

Rys. 13. Liczba osób korzystających z sieci gazowej w wybranych małych miastach w latach 2003-2013. Źródło: dane GUS, opracowanie własne

Fig. 13. The number of people using the gas network in selected small towns in the years 2003-2013. Source: GUS, own elaboration

Ostatnim elementem badania była analiza powierzchni użytkowej mieszkania przypadająca na 1 mieszkańca. W przeciągu ostatnich 11 lat powierzchnia nieznacznie wzrosła i w 2013r. wyniosła od ok. 20 m2/os. w Stroniu Śląskim do ok. $35 \mathrm{~m} 2 /$ os. w Szklarskiej Porębie. Wyniki są porównywalne do średnich krajowych prezentowanych w badaniach Jana Korniłowicza z 2007r., w których ukazuje on średnio 22,8 $\mathrm{m} 2$ mieszkania na 1 osobę [14]. Porównując to z badanymi w małych miastach, zaledwie 2 jednostki miejskie: Głuszyca i Stronie Śląskie w 2007r. znalazłyby się poniżej średniej krajowej. 


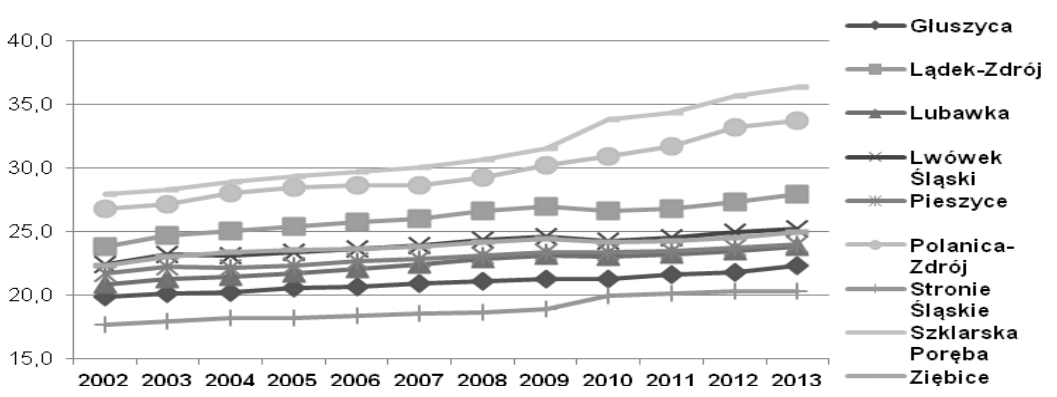

Rys. 14. Powierzchnia użytkowa mieszkania $\mathrm{w} \mathrm{m} 2$ na 1 os. w wybranych małych miastach w latach 2003-2013. Źródło: dane GUS, opracowanie własne

Fig. 14. Usable floor space in $\mathrm{m} 2$ per 1 person in selected small towns in the years 2003-2013. Source: GUS, own elaboration

\section{Podsumowanie}

Rewitalizacja to ,przywrócenie do życia”, nadanie nowego znaczenia terenom zapomnianym, opuszczonym i wyludnionym. Poprawa standardów zasobów mieszkaniowych w małych miastach województwa dolnośląskiego to tylko jeden z ważnych elementów, który należy poprawić do sprawnego funkcjonowania każdej jednostki miejskiej. Nie zapominając o naprawie relacji społecznych i umocnieniu tożsamości z miejscem zamieszkania. To w jaki sposób będzie wyglądało środowisko życia mieszkańców, będzie miało odzwierciedlenie w ich komfortowym funkcjonowaniu w danej przestrzeni. Kluczowym słowem w tytule jest rewitalizacja, sama modernizacja, czy remont budynków, nie będzie w stanie rozwiązać wszystkich problemów małych miast do 10 tys. mieszkańców, które zostały zaprezentowane w niniejszym artykule. Rewitalizacja jak wcześniej wspomniano to zmiany z dziedzin technologicznych, społecznych i przestrzennych. Kompleksowe i interdyscyplinarne znaczenie procesu będzie miało tutaj zasadniczą rolę. Największym problemem jest niewątpliwie różnorodność we własności danych obiektów w zabudowie śródmiejskiej, jednak w większości są to zasoby gminy. Bariery finansowe może rozwiązać dofinansowanie ze strony Unii Europejskiej. Pomoc jaką niesie za sobą wstąpienie Polski do państw Unii Europejskiej, m.in. dzięki Programowi Rozwoju Obszarów Wiejskich w latach 2014-2020, trzeba umiejętnie wykorzystać i poprawić środowisko życia mieszkańców małych miast. Atrakcyjne urbanistycznie, kulturowo i historycznie centralne obszary miasteczek wymagają szczególnej opieki i konstruktywnych programów działań naprawczych w celu zachowania tych walorów dla przyszłych pokoleń w myśl idei zrównoważonego rozwoju. 


\section{Literatura}

[1] Stettner M.: Rewitalizacja a obraz miasta, czyli znaczenie procesów odnowy przestrzeni małych miast dla społeczności lokalnej, Praca zbiorowa pod red. Skowronek J. Innowacyjne rozwiązania rewitalizacji terenów zdegradowanych, CBiDGP, LędzinyKatowice 2015, s. 269.

[2] Europejska Rada Urbanistów: Nowa Karta Ateńska 2003 Wizja miast XXI wieku, Wydawnictwo Alinea, Firenze 2003, s. 16.

[3] Rybka A., Walicka-Góral B.: Rewitalizacja komunalnych zasobów mieszkaniowych, Czasopismo techniczne Architektura, Zeszyt 14, Wydawnictwo Politechniki Krakowskiej, Kraków 2010, s. 162.

[4] Kaczmarek S.: Rewitalizacja terenów poprzemysłowych Nowy wymiar w rozwoju miast, Wydawnictwo Uniwersytetu Łódzkiego, Łódź 2001, s. 22-23.

[5] Skalski K.: Rewitalizacja obszarów zabytkowej zabudowy, Praca zbiorowa pod red. Jurek K., Majchrzak M. Lokalne strategie mieszkaniowe oraz programy gospodarowania zasobem mieszkaniowym gmin, Urząd Mieszkalnictwa i Rozwoju Miast, Kraków 2001.

[6] Hajduga P.: Rewitalizacja przestrzeni śródmiejskiej na przykładzie Świdnicy - wybrane aspekty, Gospodarka i przestrzeń, Prace naukowe Uniwersytetu Ekonomicznego we Wrocławiu, nr 341, Wrocław 2014, s. 39.

[7] Chmielewski J. M.: Teoria urbanistyki w projektowaniu i planowaniu miast, Oficyna Wydawnicza Politechniki Warszawskiej, Warszawa 2005, s. 152.

[8] Muzioł-Węcławowicz A.: Rewitalizacja dzielnic śródmiejskich, Praca zbiorowa pod red. Jarczewski W. Przestrzenne aspekty rewitalizacji - śródmieścia, blokowiska, tereny poprzemysłowe, pokolejowe i powojskowe, Instytut Rozwoju Miast, Kraków 2009, s. $25-85$.

[9] Fornagiel K.: Rewitalizacja miast a potrzeby społeczne, Czasopismo techniczne Architektura, Zeszyt 12, Wydawnictwo Politechniki Krakowskiej, Kraków 2012, s. 182.

[10] Krzysztofek K.: Tendencje zmian w przestrzeni późnonowoczesnego miasta, Praca zbiorowa pod red. Jałowiecki B. i in. Przemiany miasta: wokół socjologii Aleksandra Wallisa, Wydawnictwo Naukowe „Scholar”, Warszawa 2005, s. 43.

[11] Jarczewski W.: Przestrzenne aspekty rewitalizacji - śródmieścia, blokowiska, tereny poprzemysłowe, pokolejowe i powojskowe, Instytut Rozwoju Miast, Kraków 2009, s. 291.

[12] Boryczka E. M.: Koncepcje Town Centre Management w procesie rewitalizacji obszarów śródmiejskich polskich miast, Gospodarka lokalna w teorii i praktyce, Prace naukowe Uniwersytetu Ekonomicznego we Wrocławiu, nr 332, Wrocław 2014, s. $158-159$.

[13] http://euroeko.eu/program-rozwoju-obszarow-wiejskich/ \{dostęp: 20 czerwca 2015\}.

[14] Korniłowicz J.: Stan mieszkalnictwa w Polsce, Problemy Rozwoju Miast, Wydawnictwo IRM, numer 3, Kraków 2009, s. 89. 


\section{REVITALIZATION OF HOUSING STOCK IN TOWNS TO 10 THOUSAND RESIDENTS A CHANCE FOR DEVELOPMENT SMALL TOWNS}

\section{S u m m a r y}

Today's small towns have numerous urban and social problems. The demographic imbalance, lack of economic potential degradation of central areas in the city, depopulation and devastation of city centers are the main aspects on which the author points out in her article. How to stop the destructive process of spatial and social and lead to sustainable development. Revitalization as a comprehensive action can be a good option. The article presents research all the small town to 10 thousand. residents (54) in Lower Silesia in terms of demographic and economic changes (the number of population divided into groups economic, migration balance and natural increase), and as a result of the delimitation chosen 9 (Głuszyca, Lądek-Zdrój, Lubawka, Lwówek Śląski, Pieszyce, Polanica-Zdrój, Stronie Śląskie, Szklarska Poręba, Ziębice) in the worst socio-economic condition and tested them for state housing stock (access to the water mains, sewage systems and gas, the number of vacant space and space for 1 inhabitant). The aim of the study was to show the problem of degradation of the central areas in the small towns up to 10,000 inhabitants and an attempt to define conclusions for the authorities of local government units, in order to use for example the European Rural Development Programme, as a good practice. Undoubtedly, a big problem in the process of repair of the central areas in the town is diversity of building in terms of ownership structure, but for the sake of the majority in the municipal resource, you can apply corrective EU programs.

Keywords: modernization, the European Rural Development Programme, downtown, demographic balance, sanitary installations

DOI:10.7862/rb.2016.228

Przestano do redakcji: $11.10 .2015 \mathrm{r}$.

Przyjęto do druku: 30.11.2016 r. 